\title{
Migration and the Rule of Law
}

\section{External Border Control Techniques in the EU as a Challenge to the Principle of Non-Refoulement}

\author{
Iris Goldner Lang* and Boldizsár Nagy**
}

Principle of non-refoulement protected by EU law - National practices Deterrence - Pushbacks - Border police deterrence - Reaction of EU institutions - Legal uncertainties - 'Safe country of origin' - 'First country of asylum' - 'Safe third country' - EU values - New Pact on Migration and Asylum

\section{INTRODUCTION}

Over the past decade the EU has witnessed an increasing number of third-country nationals trying to reach its borders to find a safe haven there. In these difficult times, both the EU institutions and its member states have continued to proclaim their adherence to the right to seek asylum and the principle of non-refoulement, while at the same time exercising (member states) and tolerating (EU institutions) sometimes rigid border policies which have, in practice, repeatedly caused the circumvention or breaches of these rules.

The aim of this paper is twofold. First, it will show that there is a substantive change in the member states' border practices and their willingness to admit thirdcountry nationals to refugee status determination procedures, compared to the pre-2010 period. Second, the paper will highlight that the change in the member states' practical approach towards non-refoulement has taken place without

*Professor Iris Goldner Lang, PhD, is a Jean Monnet Professor of EU Law and Holder of the UNESCO Chair on Free Movement of People, Migration and Inter-Cultural Dialogue, University of Zagreb.

**Boldizsár Nagy is Associate Professor in the International Relations Department, Central European University, Vienna. This paper is linked to the 3rd UNESCO Chair conference: 'Migration and the Rule of Law', held in Zagreb on 17 January 2020.

European Constitutional Law Review, 17: 442-470, 2021

(C) The Author(s), 2021. Published by Cambridge University Press on behalf of European Constitutional Law Review. This is an Open Access article, distributed under the terms of the Creative Commons Attribution licence (http://creativecommons.org/licenses/by/4.0/), which permits unrestricted re-use, distribution, and reproduction in any medium, provided the original work is properly cited. doi:10.1017/S1574019621000249 
altering a single word in the definition of non-refoulement in EU primary and secondary law. Consequently, the gap between the EU's constitutional, normative expectations and member states' practices has been widening, leading to tension between the reality and the law, which even the new Pact on Migration and Asylum (hereinafter: Migration Pact) may be unable to eliminate. ${ }^{1}$

It is not possible to pinpoint a moment in EU history when the change in member states' border practices took place. Consequently, there is no hard dividing line between developments in the pre-2010 period and the second decade of the $21^{\text {st }}$ century, but one can make some general observations which differentiate the two periods. The first decade of the millennium was still 'fair weather', to borrow Hailbronner's metaphor, who once said that the EU's asylum acquis (the Common European Asylum System) was developed for fair weather conditions and not for a storm. ${ }^{2}$ Before the Arab Spring, the number of asylum seekers in the EU was low, ranging from 150,000 to 230,000 , and a significant number of EU member states took their fair share in receiving them. ${ }^{3}$ The recast of the Common European Asylum System was in the making, concentrating on how to streamline the reformulated rules and how to make them conform better with the Charter of Fundamental Rights and the practice of the European Court of Human Rights. ${ }^{4}$

At the beginning of the second decade, member states gradually started to exploit legal uncertainties and they occasionally committed direct breaches of human rights obligations, including refoulement. A timely and adequate response from the EU institutions was mostly lacking, leading to the conclusion that unlawful border practices were a failure on the side of both the EU and its member states.

The text will be divided into five sections. Following this introduction, the second section will provide the theoretical foundations by recalling the multiple

\footnotetext{
${ }^{1}$ Communication from the Commission to the European Parliament, the Council, the European Economic and Social Committee and the Committee of the Regions on a New Pact on Migration And Asylum, COM(2020) 609 final, 23 September 2020, 〈https://ec.europa.eu/ info/publications/migration-and-asylum-package-new-pact-migration-and-asylum-documentsadopted-23-september-2020_en $\rangle$, visited 13 July 2021.

${ }^{2}$ Referred to in M. Den Heijer et al., 'Coercion, Prohibition, and Great Expectations. The Continuing Failure of the Common European Asylum System', 53 Common Market Law Review (2016) p. 614.

${ }^{3}$ In the period between 2008 and 2010, 11 states participating in the Dublin system had more than 10,000 but fewer than 50,000 asylum applications. France was the only one surpassing the 50,000 upper limit: in 2010 it had 52,725 first-time asylum applications. Source: Eurostat, 〈https:// appsso.eurostat.ec.europa.eu/nui/show.do?dataset $=$ migr_asyappctza\&lang=en $\rangle$, visited 13 July 2021.

${ }^{4}$ See for example the Commission Staff's working paper accompanying the Commission's First Annual Report on Immigration and Asylum (2009) SEC(2010) 535 final of 6 May 2010, p. 33: 'The aim is to offer a higher degree of protection to victims of persecutions and to further harmonise and consolidate substantive and procedural standards of protection across the Union'.
} 
definitions of non-refoulement, by elaborating the definition which is followed in this text and by engaging with the loopholes which member states have recently started to exploit. The third section will address deterrence techniques exercised by a number of member states to keep migrants and refugees outside their borders and to prevent refugees' access to meaningful protection. It will start by focusing on pushbacks and border police obstruction techniques and then move on to subtler techniques which are used in administrative procedures, and which exploit legal uncertainties by relying on the concepts of the 'safe third country', 'first country of asylum' and 'safe country of origin'. This section will show that these deterrence techniques are not capable of insulating the respective member state from its non-refoulement duty and liability under EU law and the most recent case law of the European Court of Human Rights. The fourth section will problematise the relationship between non-refoulement and the Commission's Migration Pact by discussing the difficulties the new legislative proposals could create in respecting asylum seekers' fundamental rights and member states' non-refoulement obligations. The concluding section will summarise the main findings.

\section{Non-REFOUlEMENT AND DEFECTOR STATES}

Defining non-refoulement is superfluous. On the one hand, its meaning is assumed by the professional public. On the other hand, it has countless meanings and agreement will never be reached on only one true definition. ${ }^{5}$ The following three competing meanings of non-refoulement are the most frequent. According to the first one, it only refers to (recognised) refugees who are already within the asylum country and are threatened with persecution for reasons of race, religion, nationality, political opinion, or belonging to a particular social group. ${ }^{6}$ In addition to the above, according to the second definition, it extends to asylum seekers threatened with the above types of persecution, who need not be within the territory of the state which is obliged to respect non-refoulement. ${ }^{7}$ Finally, the third, very broad meaning, derived from human rights law, entails the absolute

${ }^{5}$ T. Gammeltoft-Hansen, Access to Asylum: International Refugee Law and the Globalisation of Migration Control (Cambridge Studies in International and Comparative Law) (Cambridge University Press 2011) p. 45; V. Moreno-Lax, Accessing Asylum in Europe. Extraterritorial Border Controls and Refugee Rights under EU Law (Oxford University Press 2017) p. 249.

${ }^{6}$ For a classical formulation, see K. Hailbronner, 'Non-refoulement and "Humanitarian" Refugees: Customary International Law or Wishful Thinking?', 26(4) Virginia Journal of International Law (1986) p. 862, recalling also the similar views of Atle Grahl-Madsen.

${ }^{7}$ For example J. Hathaway, The Rights of Refugees Under International Law (Cambridge University Press 2005) p. 304. 
prohibition of returning anyone to torture, inhuman or degrading treatment or punishment. $^{8}$

To summarise the uncertainties, there are debates concerning the beneficiaries (recognised refugees; asylum seekers; anyone), ${ }^{9}$ the threatening harm (persecution; serious harm taking the form of torture, inhuman or degrading treatment or punishment; other grave breaches of human rights), ${ }^{10}$ the territorial/jurisdictional scope of the principle (within the territory (expulsion and return); non-admittance at the border; extraterritorially, but within the jurisdiction of the state; extraterritorially, but under the effective control of the state and; even in the country of origin) ${ }^{11}$ and the legal nature of the principle (binding only for the parties to the Geneva Convention ${ }^{12}$ and the relevant human rights treaties; binding based on customary law; binding based on ius cogens)..$^{13}$ This article has to cut the Gordian knot: it construes non-refoulement broadly, as formulated by Guy Godwin-Gill and Jane McAdam:

${ }^{8}$ E. Lauterpacht and D.1. Bethlehem, 'The Scope and Content of the Principle of Non-refoulement: Opinion', in E. Feller et al. (eds.), Refugee Protection in International Law: UNHCR's Global Consultations on International Protection (Cambridge University Press 2003).

${ }^{9}$ Additionally, according to the judgment of the ECtHR in Saadi, the conduct of the beneficiary is immaterial, as 'the nature of the offence allegedly committed by the applicant is ... irrelevant': ECtHR 28 February 2008, No. 37201/06, Saadi v Italy, para 127.

${ }^{10}$ The ECtHR clarified that there needs to be 'substantial grounds for believing' that the individual faces a 'real risk of exposure to torture or inhuman or degrading treatment or punishment upon return': ECtHR 7 July 1989, No. 14038/88, Soering v The United Kingdom, para 88.

${ }^{11}$ The ECtHR has confirmed that the existence of de facto powers creates de iure responsibilities for the Contracting State: ECtHR 2 March 2010, No. 61498/08, Al-Saadoon and Mufdhi v the United Kingdom.

${ }^{12}$ Convention Relating to the Status of Refugees (adopted 28 July 1951, entered into force 22 April 1954) 189 UNTS 137 and Protocol Relating to the Status of Refugees (adopted 31 January 1967, entered into force 4 October 1967) 606 UNTS 267.

${ }^{13}$ Even this is not an exhaustive list of uncertainties. There are a number of further issues such as: is it a principle or a rule? Does it apply in the same way in respect of individual arrivals and in the case where a large number of asylum seeker arrives within a short period of time? When is refoulement indirect? Are there exceptions or is the command absolute? The ECJ has given guidance on a number of contentious issues. In its judgment in $\mathrm{LH}$ it concluded that EU law precludes national legislation which allows an asylum application to be rejected as inadmissible on the ground that the applicant arrived on the territory of the host member state via a state in which that person was not exposed to persecution or a risk of serious harm, or in which a sufficient degree of protection is guaranteed: ECJ 19 March 2020, Case C-564/18, LH v Bevándorlási és Menekültügyi Hivatal, p. 56. Furthermore, in MP, the Grand Chamber of the ECJ stated - in line with the ECtHR's judgment in Paposhvili - that the removal of a third-country national suffering from a serious illness to a country where appropriate treatment is not available may constitute an infringement of the principle of non-refoulement: ECJ 24 April 2018, Case C-353/16, MP v Secretary of State for the Home Department, p. 44. See also the judgment in $M, X$ and $X$, mentioned later in the text: ECJ 14 May 2019, Joined Cases C-391/16, C-77/17, $M, X$ and $X$. 
Non-refoulement extends in principle, therefore, to every individual who has a wellfounded fear of persecution, or where there are substantial grounds for believing that he or she would be in danger of torture, inhuman or degrading treatment or punishment if returned to a particular country. ${ }^{14}$

For the sake of precision, it should be added that this paper embraces the definition which encompasses individuals at the stage when they claim to be within the ambit of the definition no matter whether they have managed to make an asylum application or not (due to the fact that they have been expelled or pushed back) and even though their refugee status has not been established by any formal procedure or has been revoked. This is in line with the judgment of the Court of Justice in $M, X$ and $X$, where the Grand Chamber confirmed that it is contrary to EU law to return ('refouler') or expel a person whose refugee status has been revoked or refused due to the fact that there are reasonable grounds for regarding him or her a danger to the security of the host member state or due to the fact that he or she has been convicted of a particularly serious crime, if refoulement or expulsion would expose that individual to the risk of exposure to torture or to other inhuman or degrading treatment or punishment. ${ }^{15}$

However, there is a gap between the principle of non-refoulement and the provision of asylum, understood as the right to remain on the state territory at least as long as the person is in need of international protection. Asylum always entails non-refoulement, but the opposite is not true: non-refoulement does not entail the right to obtain asylum in the country observing the prohibition of expulsion or return. As Vincent Chetail notes, 'the Geneva Convention was carefully drafted to make sure that no obligation to grant asylum was explicitly imposed on States parties. ${ }^{16}$

This gap was not entirely closed by Article 18 of the Charter of Fundamental Rights, which prescribes that: 'the right to asylum shall be guaranteed with due respect for the rules of the Geneva Convention .... and in accordance with the Treaty on the European Union and the Treaty on the Functioning of the European Union'. First, there is major doctrinal uncertainty as to the meaning of Article 18, especially regarding the question whether it creates an independent right or simply reformulates refugee status. ${ }^{17}$ Cathryn Costello claims that the full

\footnotetext{
${ }^{14}$ G.S. Goodwin-Gill and J. McAdam, The Refugee in International Law (Oxford University Press 2007) p. 234.

${ }^{15} M, X$ and $X$, supra n. 13, paras. 95 and 110 .

${ }^{16}$ V. Chetail, International Migration Law (Oxford University Press 2019) p. 191.

${ }^{17} \mathrm{M}$. Kellerbauer et al. (eds.), The EU Treaties and the Charter of Fundamental Rights: A Commentary (Oxford University Press 2019) p. 2153-2154; V. Moreno-Lax, Accessing Asylum in Europe. Extraterritorial Border Controls and Refugee Rights under EU Law (Oxford University Press 2017) p. 371.
} 
potential of this article still has to be explored. ${ }^{18}$ Vincent Chetail warns that Article 18, which is 'devoted to asylum is of modest reach, as it does not create new obligations'. ${ }^{19}$ Even Violeta Moreno-Lax - who claims that refugees have a right to asylum and asylum seekers have a right to leave any country and seek asylum in the EU - does not go as far as to suggest that the mere action of applying for asylum entails the right to asylum. ${ }^{20}$ Consequently, the gap between nonrefoulement and asylum has not been closed by the Charter, beyond the fact that beneficiaries of international protection, whose status has been recognised, are entitled to a residence permit in the recognising state, according to Article 24 of the Qualification Directive. ${ }^{21}$

Therefore, it is established that the right to seek asylum differs from the right to asylum. EU member states must respect the right to seek asylum, but they claim not to be obliged to conduct a full refugee status determination procedure if protection can be offered by another, 'responsible' state, be it another member state or a 'safe third state'. ${ }^{22}$ According to this interpretation of the principle of nonrefoulement, the principle protects the right to seek asylum in the state which has the jurisdiction over the respective third-country national, but does not exclude the possibility for asylum (meaning the right to stay and the right to enjoy the entitlements of a protected person) to be assessed and granted in a totally different state.

This article argues that EU member states' border practices and their unwillingness to admit third-country nationals to a refugee status determination procedure on their territory can result in refoulement. Even though member states mostly avoid direct refoulement to the country or territory of origin, which is threatening the third-country national with persecution or serious harm, they also avoid offering protection within their territory. Deterrence and responsibility shifting is the name of the game played by defector states. They evade their obligations partly by stretching the interpretation of the rules forming part of the

\footnotetext{
${ }^{18} \mathrm{C}$. Costello, The Human Rights of Migrants and Refugees in European Law (Oxford Studies in European Law) Oxford University Press 2016) p. 49 and also p. 249.

${ }^{19}$ V. Chetail, 'The Common European Asylum System: Bric-à- Brac or System?', in P. De Bruycker and F. Maiani (eds.), Reforming the Common European Asylum System: The New European Refugee Law (Martinus Nijhoff 2016) p. 21.

${ }^{20}$ Moreno-Lax, supra n. 17 , p. 378-379.

${ }^{21}$ Directive 2011/95/EU of the European Parliament and of the Council of 13 December 2011 on standards for the qualification of third-country nationals or stateless persons as beneficiaries of international protection, for a uniform status for refugees or for persons eligible for subsidiary protection, and for the content of the protection granted, OJ L 337, 20.12.2011, p. 9.

${ }^{22}$ See the analysis of N.D. and N.T. later in the text, stressing the importance of the irregularity of arrival if there was a possibility for regular access as well: ECtHR 13 February 2020, Nos. 8675/15 and 8697/15, N.D. and N.T. v Spain, Applications.
} 
asylum acquis and partly by conducting practices wholly incompatible with EU law, including the EU fundamental rights framework.

The former tactic has been present from the outset and the danger posed by it was noted in the early commentaries of the acquis, but the latter was inconceivable until recently. In 1990, James Hathaway observed that:

[w]hile continuing formally to proclaim their commitment to the sheltering of all refugees, industrialized states are busily building upon the Convention's guarantee of domestic procedural control in order to construct the maze of visa controls, 'direct flight' rules, screening mechanisms, and unfair determination systems intended to deter refugees from the Third World. ${ }^{23}$

The late 1980s and the early 1990s were already replete with complaints about restricting the flow of asylum seekers, ${ }^{24}$ increased restrictions on asylum, particularly in Western Europe ${ }^{25}$ and statements such as 'asylum in the West is at a crossroads' because governments are 'having difficulty reconciling the rights of refugees to a fair determination of their claims to asylum with [their] own need to maintain an effective immigrant control mechanism'. ${ }^{26}$ What is new is the readiness of some member states to frame defection from and infringement of EU asylum and human rights norms as open policy aimed at rewriting the law, by abandoning some of the values on which the $\mathrm{EU}$ is built. The following two quotations and two national practices stand as illustrations. The first quotation comes from the Hungarian Parliament which adopted a resolution, entitled 'A message to the leaders of the European Union' in the autumn of 2015 amidst the flight of Syrian and other persons in need of protection. The message avoided the terms 'refugee' and 'asylum seeker' and referred to all those seeking a new life as 'illegal migrants':

[w]aves of illegal immigration threaten Europe with explosion ... The European Union is responsible for the emergence of this situation ... Irresponsible are the European politicians, who, with the illusion of a better life, encourage the

${ }^{23} \mathrm{~J}$. Hathaway, 'A Reconsideration of the Underlying Premise of Refugee Law', 31(1) Harvard International Law Journal (Winter 1990) p. 179.

${ }^{24} \mathrm{M}$. Fullerton, 'Restricting the Flow of Asylum-Seekers in Belgium, Denmark, the Federal Republic of Germany, and the Netherlands: New Challenges to the Geneva Convention Relating to the Status of Refugees and the European Convention on Human Rights', 29 Virginia Journal of International Law (Fall 1988) p. 35.

${ }^{25}$ D. Joly, 'The Porous Dam: European Harmonization on Asylum in the Nineties', 6(2) International Journal of Refugee Law (1994) p. 159.

${ }^{26}$ G. Loescher, Beyond Charity: International Cooperation and the Global Refugee Crisis (Oxford University Press 1993) p. 127. 
immigrants to leave everything behind and, by risking their lives, set out towards Europe $\ldots$ We have the right to defend our culture, language, values $\ldots{ }^{27}$

The second quotation comes from Theo Franken, then Belgian minister for immigration, who stated in 2018: 'Aren't there any safe ports in North Africa? Those who come to Europe should lose their right to asylum'. ${ }^{28}$ Finally, the closing of the Italian ports by the former Italian Interior Minister Matteo Salvini ${ }^{29}$ and Greek open pushbacks further illustrate national illegal practices which are incompatible with the EU fundamental rights framework. ${ }^{30}$

\section{DeterRence techniQues}

Member states use a number of techniques to deter migrants and refugees from entering their territories or from accessing the asylum procedure. Such practices can result in the violation of the principle of non-refoulement. On the one hand, by employing a spectrum of non-entrée practices - such as strict visa regimes, carrier sanctions, pushback operations on the high seas and arrangements with third countries - member states deter individuals from even entering their state territories. ${ }^{31}$ On the other hand, different non-admission techniques enable member states to prevent individuals who have already entered the state territory from accessing the asylum procedure or they accelerate or shorten the procedure, almost automatically establishing ineligibility, thus jeopardising the right to seek asylum and be protected by non-refoulement. This way, asylum seekers who have already arrived on the national territory, which relies on the notions of 'safe third country', 'first country of asylum' or 'safe country of origin', are retroactively

\footnotetext{
${ }^{27}$ Resolution 36/2015 (IX. 22) of the Parliament, Magyar Közlöny No. 136 of 22 September 2015, 〈http://www.magyarkozlony.hu/dokumentumok/30d4e493298b407e098990414cb8387 e7clcaaf8/megtekintes $\rangle$, visited 13 July 2021.

${ }^{28}$ S. Sciorilli Borrelli, 'Belgian Minister: Europe Needs Australian Approach to Migration', Politico, 16 June 2018, 〈https:/www.politico.eu/article/theo-francken-migration-belgian-ministersays-europe-needs-australian-approach/ $\rangle$, visited 13 July 2021.

${ }^{29}$ L. Tondo, 'Matteo Salvini Goes on Trial Over Migrant Kidnapping Charges', The Guardian, 2 October 2020, 〈https://www.theguardian.com/world/2020/oct/02/matteo-salvini-set-to-be-triedover-migrant-kidnapping-charges-italy $\rangle$, visited 13 July 2021.

${ }^{30}$ E. Becatoros, 'Minister: Over 10,000 Migrants Stopped from Entering Greece', Ekathimerini.com, 2 September 2020, 〈https://www.ekathimerini.com/news/256498/ministerover-10-000-migrants-stopped-from-entering-greece/ $\rangle$, visited 13 July 2021.

${ }^{31}$ On non-entrée practices, see J.C. Hathaway and T. Gammeltoft-Hansen, 'Non-Refoulement in a World of Cooperative Deterrence', 53(2) Columbia Journal of Transnational Law (2015) p. 235.
} 
excluded from the asylum procedure. ${ }^{32}$ Apart from non-entrée and nonadmission practices, there are a number of other indirect deterrence measures that can make the host member state less attractive for refugees. ${ }^{33}$

Such deterrence practices often result in the violation of the right to seek asylum and be protected by non-refoulement and are, in such cases, contrary to the standards prescribed by both international and EU asylum and human rights law, to which EU member states have committed themselves. The aim of this section is to discuss the rising trend of deterrence practices at the EU's external border, explain in which cases these practices depart from the principle of non-refoulement, and point to the ambiguities emerging in this field, partly due to the silent and at times even supportive reactions of EU institutions and partly due to the European Court of Human Rights' recent case law. These developments can be viewed as a process of member states' and EU institutions' withdrawal from the norms on the right to seek asylum and be protected by non-refoulement, without changing the wording of EU primary and secondary law. ${ }^{34}$

The section will concentrate on two types of escape techniques. The first sub-section will discuss pushbacks and border police obstructions whose use at the EU's land and sea border has significantly increased over the past few years. The second sub-section will concentrate on the way that member states, in administrative procedures, exploit legal uncertainties through the concepts of 'safe third country', first country of asylum' and 'safe country of origin'. It will be suggested that, with the member states' frequent application of these techniques and their acceptance by the EU institutions, the EU is tacitly abandoning its commitment to providing meaningful protection to asylum seekers and is shifting away from Union values. This shift could be reinforced if the package of legislative proposals accompanying the Migration Pact is adopted. ${ }^{35}$

\footnotetext{
${ }^{32}$ On non-admission, see J. Vedsted-Hansen, 'Non-admission Policies and the Right to Protection: Refugees' Choice versus States' Exclusion?', in F. Nicholson and P. Twomey (eds.), Refugee Rights and Realities: Evolving International Concepts and Regimes (Cambridge University Press 1999) p. 269.

${ }^{33}$ T. Gammeltoft-Hansen and N.F. Tan, 'The End of the Deterrence Paradigm? Future Directions for Global Refugee Policy', 5(1) Journal on Migration and Human Security (2017) p. 28 at p. 38.

${ }^{34} \mathrm{On}$ the view that member states' violations of EU law can be viewed as a process of political withdrawal or 'exit' from certain parts of the commonly adopted EU migration and asylum law, see I. Goldner Lang, 'No Solidarity without Loyalty: Why Do Member States Violate EU Migration and Asylum Law and What Can Be Done?', 22(1) European Journal of Migration and Law (2020) p. 39.

${ }^{35}$ For discussion of the latter, see the section headed 'Non-refoulement and the Migration Pact', below.
} 
However, before embarking on an analysis of pushbacks and other techniques, one should reflect on the reasons behind the paradoxical coexistence of national illegal deterrence practices and the EU's and its member states' official adherence to the EU and international asylum and human rights standards, including nonrefoulement. Four main groups of reasons can be discerned. First, the contradictory cohabitation of illegal practices and legal norms is the result of the tension between the EU's and its member states' human-rights-related ambitions on the one hand, and their policies of dissuading migration flows to the EU on the other hand. Second, pushbacks and border police discouragement techniques are partly the consequence of the inability of EU member states to agree on an EU-level legally binding responsibility-sharing mechanism, which would reduce the pressure on the geographically most exposed member states, which feel abandoned when facing the possibility of a new refugee influx. Third, deterrence practices are also the product of the populist and anti-migrant political and social climate in a number of member states, which is characterised by growing security concerns and xenophobic fears. Finally, the coexistence of deterrence practices and opposing legal norms is also encouraged by the incapacity of the European Commission and other EU institutions to respond by using political and legal means, such as infringement procedures, thus tacitly approving and authorising such behaviour, while formally maintaining their commitment to EU asylum and human rights standards. ${ }^{36}$

\section{Pushbacks and border police deterrence}

Imagine the following scenarios: $\mathrm{V}, \mathrm{X}, \mathrm{Y}$ and $\mathrm{Z}$ are refugees running away from a terrible civil war raging in their home country and they all fear for their lives if they have to return home. $V$ arrives at the official border-crossing point of an EU member state with a third country, but its border guards refuse him entry, as he does not have the required documents. $\mathrm{X}$ has managed to enter, by irregularly crossing the land border (the 'green border') in between regular entry points, but a border guard patrol stops her and uses force to remove her from the state's territory back to the third country from which she entered. Y gets to the border, but border guards stop him and turn him back by using physical force. Finally, $\mathrm{Z}$ is approaching the respective member state's green border. Its border guards

\footnotetext{
${ }^{36}$ According to Gammeltoft-Hansen and Tan, supra n. 33, p. 32, the logic behind the parallel processes of deterrence and continued commitment to international refugee law by developed states is premised on the concurrent commitment of less developed states towards refugee protection where most refugees reside. See also the discussions in I. Goldner Lang, 'No Solidarity Without Loyalty: Why Do Member States Violate EU Migration and Asylum Law and What Can Be Done?', 22 European Journal of Migration and Law (2020) p. 39, as well as B. Nagy, 'Hungarian Asylum Law and Policy in 2015-2016: Securitization Instead of Loyal Cooperation', 17(6) German Law Journal (2016) p. 1033.
} 
spot her moving towards the border and suspect that she intends to cross it in an unauthorised manner. They threaten her with weapons from afar, before she crosses the border, to scare her away.

The scenarios described above illustrate what, according to numerous reports and statements by non-governmental organisations and intergovernmental organisations, seem to be frequent practices of border authorities in a number of member states. ${ }^{37}$ The situations of $\mathrm{V}, \mathrm{X}$ and $\mathrm{Y}$ are covered by the term 'pushbacks', which is a nonlegal term referring to the conduct of state authorities or other agents, whose acts are attributable to the state, preventing intended entry or forcing migrants back over a land state border or from international or territorial waters to another jurisdiction or to maritime zones not under state jurisdiction, without an individual assessment of their circumstances or the possibility for them to apply for international protection or to put forward arguments against such conduct. ${ }^{38}$ Due to the expedited and often collective character of these actions, which deprive refugees, whose status has not yet been recognised, of the possibility to seek asylum and to explain their individual circumstances, pushbacks violate the right to be protected against refoulement in cases where pushing the individual back to another jurisdiction would result in the risk of serious violations of human rights. On the other hand, the fourth scenario of $Z$ can be characterised as 'border police deterrence'. $Z$ has not entered the member state's territory or arrived at its border-crossing point, and she is discouraged from entering from afar, without any physical contact.

As regards the first scenario, taking place at the official border-crossing point, Articles 6 and 8 of the Asylum Procedures Directive ${ }^{39}$ and Article 4 of the Schengen Borders Code $^{40}$ bind border guards checking documents at the

\footnotetext{
${ }^{37}$ For an overview of different reports on pushbacks across a number of member states, see Fundamental Rights Agency (FRA), 'Migration: Key Fundamental Rights Concerns, 1.4.2020 30.6.2020', Quarterly Bulletin (2020), 〈https://fra.europa.eu/sites/default/files/fra_uploads/fra2020-migration-bulletin-3_en.pdf $\rangle$, visited 13 July 2021. See also country reports by the European Centre for Refugees and Exiles and Asylum Information Database, 〈https://www. asylumineurope.org/reports $\rangle$, visited 13 July 2021; and the European Network of National Human Rights Institutions (ENHRI), 'Protecting Human Rights of Migrants at the Borders: Evidence and Work of European National Human Rights Institutions' (2019), 〈http://ennhri. $\mathrm{org} / \mathrm{wp}$-content/uploads/2020/03/Protecting-human-rights-of-migrants-at-the-borders-Evidence-andwork-of-European-NHRIs-December-2019-1.pdf), visited 30 September 2020.

${ }^{38}$ For a definition of pushbacks, see ECCHR (European Center for Constitutional and Human Rights) Glossary, 〈https://www.ecchr.eu/en/glossary/push-back/〉, visited 13 July 2021.

${ }^{39}$ Directive 2013/32 of the European Parliament and of the Council of 26 June 2013 on common procedures for granting and withdrawing international protection (OJ L 180, 29.6.2013, p. 60-95).

${ }^{40}$ Regulation 2016/399 of the European Parliament and of the Council of 9 March 2016 on a Union Code on the rules governing the movement of persons across borders (Schengen Borders Code) (OJ L 77, 23.3.2016, p. 1-52).
} 
border-crossing points to respect the principle of non-refoulement. The same duty applies, in the second, third and fourth scenarios, to border surveillance authorities, both on land and at sea. Article 4 of the Schengen Borders Code binds member states to act in compliance with the obligations related to access to international protection, in particular the principle of non-refoulement, when applying the Code. Article 8 of the Asylum Procedures Directive obliges border guards to provide information about the possibility to apply for asylum if there are indications that a person may wish to do so. Additionally, Article 6 of the Asylum Procedures Directive obliges border guards to inform individuals who wish to apply for asylum as to where and how to lodge an asylum application. Pushbacks, which prevent individuals from applying for asylum and from explaining their individual circumstances - no matter whether they take place at bordercrossing points or at the green border or at sea within the acting state's jurisdiction - preclude the application of Articles 6 and 8 of the Asylum Procedures Directives and can result in the violation of the border guards' duty to respect the principle of non-refoulement. Similarly, according to the European Court of Human Rights, even in cases where a state, through its agents, operating outside its territory, exercises control and authority over an individual, and thus jurisdiction, it is bound to respect its human rights obligation, including Article 3 of the European Convention on Human Rights not to subject individuals to torture, inhuman or degrading treatment or punishment. ${ }^{41}$ The Charter, equally, binds member states to respect its principles, including its Article 4, whenever they are implementing Union law, no matter whether their actions take place on the member state's territory or extraterritorially. ${ }^{42}$ Consequently, in all four situations, border guards simultaneously have to fulfil their duty to prevent unauthorised border crossings and to counter cross-border criminality, as required by Article 13 of the Schengen Border Code, while making sure that their actions do not violate their responsibilities enshrined in Articles 3 of the Convention, Article 4 of the Charter and Articles 31 and 33 of the Geneva Convention, which is part of the EU acquis. Pushbacks and border police deterrence seriously undermine this responsibility.

The Commission's reaction to pushbacks has been mild. It has openly called on several member states to investigate and take measures against pushbacks. ${ }^{43}$ However, apart from these political statements, it has not taken any concrete actions to stop them, such as initiating infringement proceedings against the

${ }^{41}$ ECtHR 23 February 2012, No. 27765/09, Hirsi Jamaa and others v Italy, para. 74.

${ }^{42}$ Art. 51 of the Charter.

${ }^{43} \mathrm{~N}$. Nielsen, 'EU Commission to Probe Croat Border Attacks on Migrants', EUobserver, 15 June 2020, 〈https://euobserver.com/migration/148639〉, visited 13 July 2021; Eurogazette, 'EU Commission Calls on Greece to Investigate Migrant Pushbacks', Society of European Journalists Eurogazette 7 July 2020, 〈https://www.eu-journalists.eu/2020/07/07/eu-commission-calls-ongreece-to-investigate-migrant-pushbacks/ $\rangle$, visited 13 July 2021. 
offending member states other than in Hungary. ${ }^{44}$ When proposing to set up a new EU mechanism to monitor pushbacks, the Commissioner for home affairs Ylva Johansson explained the need for such a mechanism by stating that the EU currently does not have the mandate to do so, though she did not specify what she meant by that. ${ }^{45}$

On the other hand, on the occasion of an attempt of thousands of migrants to cross the Greek-Turkish border in early 2020, the Commission strongly supported the Greek reaction of stopping everybody who tried to cross the border by using tear gas and rubber bullets. ${ }^{46}$ The President of the European Commission openly expressed her support for Greek actions by thanking Greece as Europe's 'shield' in blocking entry to the EU and promising financial and material support, as well as the deployment of Frontex. ${ }^{47}$ On top of this, the Commission refused to release a preliminary legal assessment of the Greek decision to temporarily freeze all asylum applications. ${ }^{48}$ It is undisputable that the developments at the Greek-Turkish border were extraordinary, since individuals were trying to cross the border in large numbers and forcefully, thus creating a threat to national security. However, when addressing the situation in Greece, the Commission did not emphasise the importance of refraining from the use of excessive force and of continuing to have a functioning asylum system, as EU law does not envisage the possibility for a member state's unilateral decision to suspend the reception of asylum applications.

The Greek Prime Minister invoked Article 78(3) TFEU, which enables the Council to adopt provisional measures, on a proposal from the Commission and in consultation with the European Parliament, for the benefit of the member state confronted by an emergency situation of a sudden migration influx. ${ }^{49}$

\footnotetext{
${ }^{44}$ ECJ 17 December 2020, Case C-808/18, European Commission v Hungary. The Court found that 'in allowing the removal of all third country nationals staying illegally in its national territory, with the exception of those of them who are suspected of having committed an offence, without observing the procedures and safeguards laid down in ... Directive 2008/115 [The Return Directive], Hungary has failed to fulfil its obligations under those provisions' (para. 266).

${ }^{45}$ Eurogazette, supra n. 43.

${ }^{46}$ G. Gotev and S. Michalopoulos, 'Erdogan Drops the "Human Bomb” on EU', Euractiv, 29 February 2020, 〈https:/www.euractiv.com/section/global-europe/news/erdogan-drops-the-humanbomb-on-eu $\rangle$, visited 13 July 2021.

${ }^{47}$ BBC News, 'EU Chief Says Greece is Europe's Shield in Migrant Crisis', 3 March 2020, $\langle$ https://www.bbc.com/news/world-europe-51721356〉, visited 13 July 2021.

${ }^{48} \mathrm{~N}$. Nielsen, 'EU Commission Keeps Asylum Report on Greece Secret', EUobserver, 21 April 2020, 〈https://euobserver.com/migration/148119〉, visited 13 July 2021.

${ }^{49}$ On 1 March 2020 Greece's Governmental National Security Council temporarily suspended all asylum applications. Greek Prime Minister announced that they were 'invoking article 78(3) TFEU to ensure full European support', 〈https://twitter.com/PrimeministerGR/status/123419292 2813267976 , visited 13 July 2021.
} 
However, as emphasised by the European Council on Refugees and Exiles and the United Nations High Commissioner for Refugees, Article 78(3) TFEU can only be employed for measures compliant with EU primary law, including the Charter of Fundamental Rights, and it cannot result in the suspension of the right to seek asylum and the principle of non-refoulement. ${ }^{50}$ Consequently, the Greek Government's reliance on Article 78(3) TFEU could not exempt Greece from the obligation to respect the principle of non-refoulement. ${ }^{51}$

The European Court of Human Rights' Grand Chamber judgment in N.D. and N.T., as discussed in this journal ${ }^{52}$ and therefore not recalled in detail here, further complicates the matter. ${ }^{53}$ The Strasbourg Court decided that the immediate return of N.D. and N.T. from Spain to Morocco, without an individualised removal procedure, did not violate either Article 4 of Protocol No. 4 (prohibition

${ }^{50}$ European Council on Refugees and Exiles, 'ECRE Statement on the Situation at the Greek Turkish Border', 3 March 2020, 〈https://www.ecre.org/ecre-statement-on-the-situation-at-thegreek-turkish-border/ $\rangle$, visited 13 July 2021; United Nations High Commissioner for Refugees, 'UNHCR Statement on the Situation at the Turkey-EU Border', 2 March 2020, 〈https:// www.unhcr.org/news/press/2020/3/5e5d08ad4/unhcr-statement-situation-turkey-eu-border.html $\rangle$, visited 13 July 2021.

${ }^{51}$ Similarly, European Commission v Hungary, supra n. 44, para. 262, the Court rejected the Hungarian argument according to which pushbacks at the Hungarian-Serbian border would be justified by relying on Art. 4(2) TEU, securing the right to derogate from EU law in matters of national security or public order.

${ }^{52}$ L. Alonso Sanz, 'Deconstructing Hirsi: the Return of Hot Returns', 16(2) EuConst (2021) p. 335.

${ }^{53}$ ECtHR 13 February 2020, Nos. 8675/15 and 8697/15, N.D. and N.T. v Spain. For analyses and critiques of the Strasbourg Court's judgment, see, for example: M. Pichl and D. Schmalz, "'Unlawful" May Not Mean Rightless: The Shocking ECtHR Grand Chamber Judgment in case N.D. and N.T.', Verfassungsblog, 14 February 2020, 〈https://verfassungsblog.de/unlawful-maynot-mean-rightless/ $\rangle$, visited 13 July 2021; C. Oviedo Moreno, 'A Painful Slap from the ECtHR and an Urgent Opportunity for Spain', Verfassungsblog, 14 February, 〈https://ver fassungsblog.de/a-painful-slap-from-the-ecthr-and-an-urgent-opportunity-for-spain/ $\rangle$, visited 13 July 2021); D. Thym, 'A Restrictionist Revolution? A Counter-Intuitive Reading of the ECtHR's N.D. \& N.T. Judgment on "Hot Expulsions", Odysseus Blog, 17 February 2020, 〈https:// eumigrationlawblog.eu/a-restrictionist-revolution-a-counter-intuitive-reading-of-the-ecthrs-n-d-n-tjudgment-on-hot-expulsions/ $/$, visited 13 July 2021; C. Hruschka, 'Hot Returns Remain Contrary to the ECHR: ND \& NT before the ECHR', Odysseus Blog, 28 February 2020, 〈https:// eumigrationlawblog.eu/hot-returns-remain-contrary-to-the-echr-nd-nt-before-the-echr/ $\rangle$, visited 13 July 2021; N. Markard, 'A Hole of Unclear Dimensions: Reading ND and NT v Spain', Odysseus Blog, 1 April 2020, 〈https://eumigrationlawblog.eu/a-hole-of-unclear-dimensionsreading-nd-and-nt-v-spain/>, visited 13 July 2021; S. Carrera, 'The Strasbourg Court Judgement N.D. and N.T. v Spain: A Carte Blanche to Push Backs at EU External Borders?, EUI Working Papers RSCAS 2020/21, 〈https://cadmus.eui.eu/bitstream/handle/1814/66629/RSCAS \%202020_21.pdf?sequence=1\&isAllowed=y , visited 13 July 2021. 
of collective expulsion) to the ECHR or Article $13 \mathrm{ECHR}$ (right to an effective remedy), as it was the consequence of the applicants' own conduct

The judgment can be seen as the European Court of Human Rights' departure from its ruling in Hirsi, where the Court decided that the interception at sea by Italian authorities of Somali and Eritrean migrants, who were travelling from Libya, and their sending back to Libya violated Article 3 ECHR, as they faced a risk of being arbitrarily returned to their countries of origin. ${ }^{54}$ However, the ruling in N.D. and N.T. does not give carte blanche to collective expulsions, but states that it is justified if it is the consequence of the applicant's own conduct, which is the case provided two conditions are met. First, what needs to be considered is whether the respective state provides 'genuine and effective access to means of legal entry, in particular border procedures for those who have arrived at the border'. ${ }^{55}$ If the answer to the first question is positive, then one needs to examine whether there is an 'absence of cogent reasons why the applicant did not make use of official entry procedures, which were based on objective facts for which the respondent State was responsible. ${ }^{56}$

However, the Court does not explain the criteria for establishing the state's responsibility in a situation where the applicant does not make use of the official entry procedures, such as asking for asylum at the official border crossing point. It seems logical that the existence of a deal with the neighbouring state, such as the EU-Turkey Statement, which has the effect of preventing individuals from getting to the border, would make that member state responsible. ${ }^{57}$ When applied to the situation at the Greek-Turkish border in February 2020, this could indicate the existence of Greek responsibility in a situation where the applicant could not use the official entry procedures because he or she was prevented from doing so by Turkey, based on the EU-Turkey Statement.

The judgment left a number of other open questions. First, it was not clear whether the Court's evaluation of the legality of expulsion applies only to cases where migrants had arrived en masse or also to cases where they had arrived individually. Neither was it clear whether the same rule would apply if migrants did not use force, but just peacefully approached the border. In other words, until M.K. and Others v Poland, ${ }^{58}$ it was unclear whether the Court would have ruled differently if an individual attempted to cross the border in a situation where there

${ }^{54}$ ECtHR 23 February 2012, No. 27765/09, Hirsi Jamaa and Others v Italy.

${ }^{55}$ N.D. and N.T. v Spain, supra n. 53, para. 201.

${ }^{56} \mathrm{Ibid}$.

${ }^{57}$ However, it is not clear why the ECtHR stated that 'even assuming that difficulties existed in physically approaching this border crossing point on the Moroccan side, no responsibility of the respondent Government for this situation has been established before the Court'.

${ }^{58}$ ECtHR 23 July 2020, Nos. 40503/17, 42902/17 and 43643/17, M.K. and Others v Poland, Applications. For a discussion on M.K. and Others v Poland, see further below. 
was no security threat, and what criteria the Court would use to measure the existence of such a threat.

The judgment in N.D. and N.T. has serious implications. Most importantly, it sends a signal to EU member states that under certain conditions it is not illegal, under the Convention human rights standards, to collectively push back thirdcountry nationals who try to enter the EU, without individually assessing their status and knowing whether they are economic migrants or refugees. From this perspective, the judgment can be viewed as the Court's endorsement of states' use of force and other deterrent activities when confronted with the possibility of a new migration influx. It is also possible that - if confronted with a similar case - the Luxembourg Court will be influenced by the European Court of Human Rights' judgment and decide that collective pushbacks in circumstances similar to those in N.D. and N.T. do not violate EU law, including the Charter of Fundamental Rights. ${ }^{59}$

Nevertheless and despite its many shortcomings and ambiguities, the judgment explicitly confirms the prohibition of refoulement, as an absolute right enshrined in Article 3 ECHR. ${ }^{60}$ However, it remains unclear how the Spanish authorities could have known, at the time they conducted the pushbacks, that their conduct would not result in refoulement, considering the fact that the pushbacks took place without first assessing the (non-)existence of N.D.'s and N.T.'s need for protection. ${ }^{61}$ On the other hand, the judgment has no effect on member states' obligations based on the Geneva Convention and EU law, both of which bind states to respect the principle of non-refoulement. Taking all this into consideration, the judgment in N.D. and N.T. does not change the fact that returning individuals at the EU border remains contrary to the letter of the law, unless they are not in need of protection, which, in return, can only be determined by examining individual circumstances on a case-by-case basis or by first examining whether the individual will have access to an adequate asylum procedure in the receiving state.

\footnotetext{
${ }^{59}$ For a discussion on the (passive) behaviour of the Court of Justice in the area of migration and asylum law, see I. Goldner Lang, 'Towards "Judicial Passivism” in EU Migration and Asylum Law?', in T. Ćapeta et al. (eds.), The Changing European Union: A Critical View on the Role of Law and Courts (Hart Publishing forthcoming), 〈https://papers.ssrn.com/sol3/papers.cfm?abstract_id= 3597017), visited 13 July 2021.

${ }^{60}$ N.D. and N.T. v Spain, supra n. 53, para. 232.

${ }^{61}$ For a critique of the judgment from the perspective of the principle of non-refoulement, see A. Lübbe, 'The Elephant in the Room: Effective Guarantee of Non-Refoulement after ECtHR N.D. and N.T?', Verfassungsblog, 19 February 2020, 〈https://verfassungsblog.de/theelephant-in-the-room/ $\rangle$, visited 13 July 2021.
} 
The European Court of Human Rights' judgment in M.K. and Others v Poland confirms this. ${ }^{62}$ In this case, involving Russian nationals who attempted to flee from Chechnya and cross the Terespol border between Poland and Belarus, the Strasbourg Court indicated that if a state removes an asylum-seeker to a third country without examining the asylum request on the merits, it must first review whether the individual will have access to an adequate asylum procedure protecting him or her against refoulement in the receiving third country. ${ }^{63}$ Since this was not the case, the Court concluded that the Polish authorities violated Article 3 ECHR and it unveiled the existence of a systematic administrative practice of pushbacks of asylum seekers at the border with Belarus. ${ }^{64}$

However, there is a notable difference between the facts in N.D. and N.T. and M.K. v Poland. Whereas in the former cases migrants had a disruptive effect at the Spanish-Moroccan border by trying to enter the Spanish territory en masse with the use of force, none of this occurred in M.K. Here, a smaller group of migrants came to the official border crossing point and applied for asylum, without using violence or breaking any laws. Consequently, the two contrasting judgments can be understood as the result of the Strasbourg Court's perception of the difference between 'good' and 'bad' migrants and of the application of the criterion of the 'applicant's own conduct', which the Court established in N.D. and N.T., as the determining factor which can justify collective expulsion. Additionally, it may be worth stressing that in N.D. and N.T. the Court confirmed that people arriving at the external border of the Schengen area have a right to be heard and have their case examined by the Schengen state, thereby condemning all border practices that reject or return people without offering them access to procedures assessing their need for protection. ${ }^{65}$

The most radical move to legalise pushback was made by Hungary. In the summer of 2020, it used Covid-19 as a pretext to adopt a law ordering the turning away of everyone who approaches the Hungarian border with a view to seeking

${ }^{62}$ M.K. and Others v Poland, Applications, supra n. 58. For an analysis of M.K. see U. Brandl, 'A Human Right to Seek Refuge at Europe's External Borders: The ECtHR Adjusts Its Case Law in M.K. vs Poland', Odysseus Blog, 11 September 2020, 〈https://eumigrationlawblog.eu/a-humanright-to-seek-refuge-at-europes-external-borders-the-ecthr-adjusts-its-case-law-in-m-k-vs-poland/ $\rangle$, visited 13 July 2021.

${ }^{63}$ M.K. and Others v Poland, supra n. 58, paras. 172 and 173.

${ }^{64}$ M.K. and Others v Poland, supra n. 58, para. 186.

${ }^{65}$ N.D. and N.T. v Spain, supra n. 53, para 209: 'The effectiveness of Convention rights requires that [states with external Schengen borders] make available genuine and effective access to means of legal entry, in particular border procedures for those who have arrived at the border. Those means should allow all persons who face persecution to submit an application for protection, based in particular on Article 3 of the Convention, under conditions which ensure that the application is processed in a manner consistent with the international norms, including the Convention'. 
protection. ${ }^{66}$ In reality, it was a reaction to the judgment of the Court of Justice in FMS and Others v Hungary. ${ }^{67}$ In its judgment, the European Court of Justice found illegal the previous system of pushing back over the border fence with Serbia all asylum seekers without the right to stay in Hungary. The Court also declared that the Hungarian practice of detaining an applicant for international protection in the transit zone was precluded by Articles 8 and 9 of Directive 2013/33, as it was based on the sole ground that the applicant was unable to provide for his or her needs. Additionally, such detention was taking place without a reasoned decision ordering the detention, without investigating the necessity and proportionality of such a measure and without the availability of judicial review of the lawfulness of the administrative decision ordering the detention. ${ }^{68}$ However, according to the new rules, applicable at least until 30 June 2021, asylum seekers approaching the Hungarian border are denied entry and are directed to the Hungarian embassy in Belgrade or Kyiv in order to declare their intention to apply for protection. Transit zones no longer function. Even those who are on Hungarian soil - with a few specific exceptions - have to leave or are escorted to the gates along the border fence and have to reach one of the two designated embassies in order to express their intention to apply for asylum in Hungary. ${ }^{69}$ The United Nations High Commissioner for Refugees immediately demanded the withdrawal of the Act, while the Commission expressed concerns and launched infringement proceedings. ${ }^{70}$

${ }^{66}$ Act LVIII adopted on 17 June 2020 on Transitional Rules related to the Cessation of the State of Danger in response to the COVID-19 situation and on Epidemiological Preparedness, 〈https:// magyarkozlony.hu/dokumentumok/b18d1fb3c742aa2bd183b15a32fe4425e603f2c2/megtekintes $\rangle$, visited 13 July 2021.

${ }^{67}$ ECJ 14 May 2020, Joined Cases C-924/19 PPU and C-925/19 PPU, FMS and Others v Országos Idegenrendeszeti Föigazgatóság Dél-alfóldi Regionális Igazgatóság and Országos Idegenrendeszeti Föigazgatóság.

${ }^{68}$ Para. 302 of the judgment. In the infringement case ECJ 17 December 2020, Case C-808/18, European Commission v Hungary, the Court declared that 'in establishing a system of systematic detention of applicants for international protection in the transit zones of Röszke and Tompa, without observing the guarantees provided for in Article 24(3) and Article 43 of Directive 2013/32 and Articles 8, 9 and 11 of Directive 2013/33' Hungary has 'failed to fulfil its obligations' (para 317).

${ }^{69}$ More details in: Hungarian Helsinki Committee, 'Hungary de facto Removes Itself from the Common European Asylum System (CEAS): Information Update by the Hungarian Helsinki Committee (HHC)', 12 August 2020, 〈https:/www.helsinki.hu/wp-content/uploads/ new-Hungarian-asylum-system-HHC-Aug-2020.pdf $\rangle$, visited 13 July 2021.

${ }^{70}$ UNHCR, 'Access to Asylum Further at Stake in Hungary', 29 June 2020, 〈https://www.unhcr. org/news/press/2020/6/5efa0f914/access-asylum-further-stake-hungary-unhcr.html $\rangle$, visited 13 July 2021. The Commission decided to launch infringement proceedings concerning the Hungarian legislation adopted in the context of the pandemic, 〈https:/ec.europa.eu/commission/ presscorner/detail/en/ip_21_3424〉, visited 18 July 2021. 
Exploiting legal uncertainties surrounding the concepts of 'safe country of origin', 'first country of asylum' and 'safe third country'

Whereas pushbacks - which prevent asylum seekers' access to meaningful protection, by denying access to the territory and asylum procedure - often amount to refoulement, the concepts of a 'safe country of origin', 'first country of asylum' and 'safe third country', which are analysed in this section, exploit the gap between non-refoulement and protection. These concepts are part of EU law but, by exploiting their inherent indeterminacy against the asylum seeker, states are often bending their meaning, which leads to a dramatic lowering of asylum standards. The aim of this section is to discuss these concepts by pointing to the most important indeterminacies related to them and by explaining why they could result in the lowering of asylum standards.

The definition of these concepts is complex. ${ }^{71}$ An abbreviated version of these definitions will be provided herewith. A 'safe country of origin' is a democratic state in which the letter of the law and everyday practice corroborate that 'there is generally and consistently no persecution, ${ }^{72}$ nor torture or inhuman or degrading treatment or punishment. ${ }^{73}$ The term 'first country of asylum' refers to a country in which the applicant has been recognised as a refugee (before moving on to the country where she applies again) or in which she otherwise enjoys 'sufficient protection', including non-refoulement and to which she will be readmitted. ${ }^{74}$ 'Safe third countries' are third countries (like the UK) in which there is neither a threat of persecution nor serious harm, non-refoulement is respected, access to the asylum procedure is guaranteed and, in which, if recognised as in need of protection, a person obtains 'protection in accordance with the Geneva Convention'. ${ }^{75}$ Additionally, the denomination of a 'safe third country' presupposes a connection between the applicant and the third country on the basis of which 'it would be reasonable for that person to go to that country'. ${ }^{76}$

The three concepts have very different underlying assumptions. In the case of a 'safe country of origin' and a 'first country of asylum', there is no need for (further) protection, as the person is not threatened with persecution or serious harm. On

\footnotetext{
${ }^{71}$ Arts. 36-37 of the Asylum Procedures Directive, supra n. 39, together with Annex I define the concept of a 'safe country of origin'; Art. 35 defines the concept of a 'first country of asylum', and Art. 38 regulates when a third country is safe.

${ }^{72}$ Art. 36(1) of the Asylum Procedures Directive, supra n. 39.

${ }^{73}$ Asylum Procedures Directive, Annex I, supra n. 39.

${ }^{74}$ Art. 35 of the Asylum Procedures Directive, supra n. 39.

${ }^{75}$ Art. 38 para 1(e) of the Asylum Procedures Directive, supra n. 39.

${ }^{76}$ Art. 38 para 2(a) of the Asylum Procedures Directive, supra n. 39.
} 
the other hand, in the case of a 'safe third country', the person may well be exposed to a risk in the country of origin, but not in the safe third country. The common denominator of all three concepts - together with the internal relocation alternative, which we do not discuss here - is that the state whose protection is expected by the asylum seeker does not accept its responsibility, either because there is no need for protection or it is already granted elsewhere, or because the approached state believes that another state should decide whether there is a need for protection. The requested state shifts the responsibility away from itself.

While the concept of a 'safe country of origin', in abstract terms, is impeccable, as it is an expression of the fact that the applicant is not a refugee as - presumably - her circumstances do not correspond to the definition, the idea of a 'first country of asylum' and of a 'safe third country' raise at least two fundamental theoretical questions. The first question is whether the asylum seeker has or should have a choice of asylum country. The second question is whether members of the international community are ready to distribute fairly among themselves the tasks related to offering protection to those in need. The individual's free choice and solidarity among states are at stake here. Both questions have generated a wealth of academic commentary, as did the issue whether these concepts are compatible with the Geneva Convention and whether their application increases the efficiency of the global or of the EU asylum system. ${ }^{77}$

A closer look at each of the debated concepts leads to the following observations. As regards 'safe country of origin', it is questionable when it can no longer be claimed that 'generally and consistently' there is no persecution, or that remedies against human rights violations are effective. Additionally, a major challenge concerning the application of the 'safe country of origin' are large discrepancies among member states' lists. ${ }^{78}$ Member states were unable to agree on a common

\footnotetext{
${ }^{77}$ R. Byrne and A. Shacknove, 'The Safe Country Notion in European Asylum', 9 Harvard Human Rights Journal (1996) p. 185; S.H. Legomsky, 'Secondary Refugee Movements and the Return of Asylum-Seekers to Third Countries: The Meaning of Effective Protection', 15 International Journal of Refugee Law (2003) p. 567; C. Costello, 'The Asylum Procedures Directive and the Proliferation of Safe Country Practices: Deterrence, Deflection and the Dismantling of International Protection?', 7 European Journal of Migration and Law (2005) p. 35; A.G. Hurwitz, The Collective Responsibility of States to Protect Refugees (Oxford University Press 2009); R. Marx, 'The European Union's Plan to Amend the "First Country of Asylum" and "Safe Third Country" Concepts', 31 IJRL (2019) p. 580.

${ }^{78}$ For a systemic demonstration of differences, see European Migration Network: Inform, 'Safe Countries of Origin' (2018), 〈https://ec.europa.eu/home-affairs/sites/homeaffairs/files/00_inform_ safe_country_of_origin_final_en_1.pdf), visited 13 July 2021.
} 
list. ${ }^{79} \mathrm{~A}$ source of concern is that the Commission in 2015 suggested Turkey as a 'safe country of origin' even though in $201423.1 \%$ of asylum applications of citizens of Turkey were well-founded. ${ }^{80}$

In connection with the 'first country of asylum', it is debatable, first, whether refugee status offers sufficient protection if the first country of asylum does not apply the Geneva Convention. Second, it is questionable which set of rights can be considered sufficient in cases where 'sufficient protection' - as the alternative to refugee status - is provided. ${ }^{81}$ Thirdly, return to the country in safety and dignity, as well as regaining protected status there, may become practically impossible.

As regards the safe third country, Hathaway and Foster, among others, ${ }^{82}$ have noted there is no positive legal authority' for arrangements 'to share-out responsibility among' states by establishing 'protection elsewhere' rules. ${ }^{83}$ Marx notes that the safe third country practice (as well as the practice of the first country of asylum), 'challenges the very foundation of the international system of collective endeavour and commitment to protection for refugees'. ${ }^{84}$ On the one hand, neither the 'safe third country' rule, nor the 'first country of asylum' rule is informed by considerations of the fair sharing of responsibility. Rather, they constitute member states' deflection from responsibility. On the other hand, 'safe third country' and 'first country of asylum' also downplay refugees' claim for protection, as the treatment expected from the 'first country of asylum' and the 'safe third country' is much poorer than the one offered by the Qualification Directive or the Geneva Convention. Cathryn Costello noted that the requirement of 'effective protection' could have developed into a 'meaningful constraint on the use and abuse of "first country of asylum" (and indeed "safe third

\footnotetext{
${ }^{79}$ Proposal for a Regulation of the European Parliament and of the Council establishing an EU common list of safe countries of origin for the purposes of Directive 2013/32/EU of the European Parliament and of the Council on common procedures for granting and withdrawing international protection, and amending Directive 2013/32/EU, (COM(2015) 452 final). The suggested list was: Albania, Bosnia and Herzegovina, Kosovo, Montenegro, North Macedonia, Serbia, Turkey. The Commission withdrew the proposal on 21 June 2020.

${ }^{80}$ Ibid., p. 6.

${ }^{81}$ For an influential response, see Legomsky, supra n. 77, p. 645-654. UNHCR's position was summarised in UN High Commissioner for Refugees (UNHCR), Legal Considerations on the Return of Asylum-seekers and Refugees from Greece to Turkey as Part of the EU-Turkey Cooperation in Tackling the Migration Crisis under the Safe Third Country and First Country of Asylum Concept, 23 March 2016, available at 〈https://www.refworld.org/docid/56f3ee3f4.html〉, visited 13 July 2021.

${ }^{82}$ V. Moreno-Lax, 'The Legality of the "Safe Third Country" Notion Contested: Insights from the Law of Treaties' in G.S. Goodwin-Gill and P. Weckel (eds.), Migration \& Refugee Protection in the 21st Century: Legal Aspects. The Hague Academy of International Law Centre for Research (Martinus Nijhoff 2015) p. 667.

${ }^{83}$ J.C. Hathaway and M. Foster, The Law of Refugee Status, 2nd edn. (Cambridge University Press 2014) p. 33.

${ }^{84}$ Marx, supra n. 77 , p. 583.
} 
country") techniques ... [but] ... the EU has thwarted its further development by using the term "sufficient protection" instead of "effective protection". ${ }^{85}$

Finally, key elements of the concept of 'safe third country' offer opportunities for actions bordering refoulement. Access to a fair and efficient refugee status determination procedure and the quality of the conditions during the procedure and after the decision, including access to human and other rights, may be missing or seriously substandard in the receiving third country. The connection to the safe third country is reduced in cases where it is decided that a third country is a 'safe third country' by reason of the applicant's mere transit through that country, ${ }^{86}$ even though according to the prevailing view transit cannot generate a reasonable expectation that the asylum seeker returns there. ${ }^{87}$

These examples prove that the uncertainties associated with the concepts of 'safe country of origin', 'first country of asylum' and 'safe third country' lead to the lack of predictability and certainty, which are essential for the functioning of the rule of law. The return of asylum seekers to Turkey, Bosnia and Herzegovina, Serbia, Iran, Jordan, Lebanon, Libya and Morocco may rely on the indeterminacy of the three concepts serving as the legal basis of the return, but they can hardly be seen as the implementation of the EU Charter right to asylum. Consequently, it is not surprising that EU member states have been condemned by major international actors and by both European Courts for having returned persons to danger and/or for exposing them to chain-refoulement. ${ }^{88}$

${ }^{85}$ Costello, supra n. 77 , p. 59.

${ }^{86}$ 'The determining authority shall consider a third country to be a safe third country for a particular applicant, [when] it has established that: (a) there is a connection between the applicant and the third country in question on the basis of which it would be reasonable for that person to go to that country, including because the applicant has transited through that third country which is geographically close to the country of origin of the applicant' (Commission's Proposal for a regulation establishing a common procedure for international protection in the Union and repealing Directive 2013/32/EU, COM (2016) 467 final, 13.7.2016). This view led Hungary to declare the inadmissibility of applications submitted by those who simply transited Serbia.

${ }^{87}$ 'UNHCR and authoritative commentators have argued that there should be a connection between the applicant and the third country in question, and that mere transit does not satisfy this criterion': B. De Witte and E.(L.) Tsourdi, 'Confrontation on Relocation - The Court of Justice Endorses the Emergency Scheme for Compulsory Relocation of Asylum Seekers within the European Union: Slovak Republic and Hungary v Council', 55 Common Market Law Review (2018) p. 1490.

${ }^{88}$ For example, see the European Council for Refugees and Exiles condemning the Greek State Council's decision finding Turkey a safe third country: ECRE, 'Greek Appeals Committees Tighten the Criterion of Sufficient Connection to Safe Third Country', 27 October 2017, 〈https://www.ecre. $\mathrm{org}$ /greek-appeals-committees-tighten-the-criterion-of-sufficient-connection-to-safe-third-country/ $\rangle$, visited 13 July 2021; ECJ 19 March 2020, Case C-564/18, LH v Bevándorlási és Menekültügyi Hivatal; ECtHR [GC] 23 February 2012, No. 27765/09, Hirsi Jamaa and Others v Italy; ECtHR 11 December 2018, No. 59793/17, M.A. and Others v Lithuania; ECtHR 23 July 2020, Nos. 40503/17, 42902/17 and 43643/17, M.K. and Others v Poland. 
Notwithstanding these points of concern, the three concepts became and have remained part of EU law and practice. ${ }^{89}$

\section{Non-refoulement and the Migration Pact}

The Commission's Migration Pact ${ }^{90}$ proclaims to adhere to the protection of fundamental rights, including the principle of non-refoulement, just like the legislation which is currently in force. ${ }^{91}$ Border control and the revamped screening exercises would continue to be bound by the principle of non-refoulement, and the same standards would apply to the newly proposed border procedures. ${ }^{92}$ However, it is questionable whether the legislative proposals contained in the Pact - if they get adopted in the form proposed by the Commission - will, in practice, manage to live up to the fundamental rights standards they set on paper. ${ }^{93}$ This is due to two

\footnotetext{
${ }^{89}$ Report from the Commission to the European Parliament and the Council on the application of Directive 2005/85 of 1 December 2005 on minimum standards on procedures in member states for granting and withdrawing refugee status $\operatorname{COM}(2010) 465$ final, Brussels, 8.9.2010, p. 10-12.

${ }^{90} \mathrm{New}$ Pact on Migration and Asylum, supra n. 1.

${ }^{91}$ The Migration Pact provides that 'all necessary guarantees will be put in place to ensure that every person would have an individual assessment and essential guarantees remain in full, with full respect for the principle of non-refoulement and fundamental rights': Communication from the Commission to the European Parliament, the Council, the European Economic and Social Committee and the Committee of the Regions on A New Pact on Migration and Asylum, section 2.1.

${ }^{92}$ Recital 5 of the Preamble to the Proposal for a Regulation introducing a screening of third country nationals at the external borders and amending Regulations (EC) No 767/2008, (EU) 2017/2226, (EU) 2018/1240 and (EU) 2019/817, COM(2020) 612 final, 23 September 2020; Recital $40 \mathrm{~h}$ of the Preamble to the amended proposal for a Regulation establishing a common procedure for international protection in the Union and repealing Directive 2013/32/EU, COM(2020) 611 final, 23 September 2020.

${ }^{93}$ For an overview of the main novelties and challenges of the Migration Pact, see D. Thym, 'European Realpolitik: Legislative Uncertainties and Operational Pitfalls of the "New" Pact on Migration and Asylum', Odysseus Blog, 28 September 2020, 〈http://eumigrationlawblog.eu/ european-realpolitik-legislative-uncertainties-und-operational-pitfalls-of-the-new-pact-on-migrationand-asylum/ $\rangle$, visited 13 July 2021; S. Peers, 'First Analysis of the EU's New Asylum Proposals', EU Law Analysis, 25 September 2020, 〈http://eulawanalysis.blogspot.com/2020/09/first-analysis-ofeus-new-asylum.html , visited 13 July 2021; J-P. Cassarino and L. Marin, 'The New Pact on Migration and Asylum: Turning European Union Territory into a Non-Territory', EU Law Analysis, 30 November 2020, 〈http://eulawanalysis.blogspot.com/2020/11/the-new-pact-on-migration-andasylum.html , visited 13 July 2021; S. Carrera, 'Whose Pact? The Cognitive Dimensions of the New EU Pact on Migration and Asylum', No. 2020-22, September 2020, 〈https://www.ceps.eu/ ceps-publications/whose-pact//, visited 13 July 2021. In general see 'Special Collection on the 'New' Migration and Asylum Pact', Odysseus Blog, 〈https://eumigrationlawblog.eu/series-on-themigration-pact-published-under-the-supervision-of-daniel-thym/ $\rangle$, visited 13 July 2021.
} 
factors. First, there is not much new in the Pact, which contradicts the Commission's statement of a 'fresh start'. ${ }^{94}$ As emphasised by Moreno-Lax, the Pact's primary focus is not on the protection of migrants and refugees, but on managing mixed flows and countering irregular arrivals. ${ }^{95}$ Second, the nature of the proposed procedures, short deadlines and demanding operational, financial and human resource requirements set by the proposals will make it extremely difficult for member states to put these rules into practice without violating asylum seekers' rights. ${ }^{96}$ Insufficient operational, personnel and financial investment into screening and border procedures could result in the poor implementation of the Migration Pact and in serious violations of individual rights, including the principle of nonrefoulement, especially in the case of a new increase in the number of arrivals. It might also trigger increased discontent and requests for stronger EU solidarity of frontline member states and mutual accusations among member states. ${ }^{97}$ It is questionable how the Commission will react to such violations and whether it will try to compensate for the deficiencies of the proposed procedures by being reluctant to start infringement proceedings against the most affected, frontline, member states if they are not able to perform.

These challenges are likely to become most apparent in the context of screening and border procedures. Screening procedures will be regulated by the Proposal for a Regulation introducing screening of third-country nationals at the external

\footnotetext{
${ }^{94}$ European Commission's Press Release on the Migration Pact, 'A Fresh Start on Migration: Building Confidence and Striking a New Balance between Responsibility and Solidarity', 23 September 2020, 〈https://ec.europa.eu/commission/presscorner/detail/en/ip_20_1706〉, visited 13 July 2021.

${ }^{95}$ V. Moreno-Lax, 'A New Common European Approach to Search and Rescue? Entrenching Proactive Containment', Odysseus Blog, 3 February 2021, 〈https://eumigrationlawblog.eu/a-newcommon-european-approach-to-search-and-rescue-entrenching-proactive-containment/ $\rangle$, visited 13 May 2021. See also P.G. Andreade, 'EU Cooperation on Migration with Partner Countries within the New Pact: New Instruments for a New Paradigm?' Odysseus Blog, 8 December 2020, 〈https:// eumigrationlawblog.eu/eu-cooperation-on-migration-with-partner-countries-within-the-new-pactnew-instruments-for-a-new-paradigm/ $\rangle$, visited 13 July 2021.

${ }^{96} \mathrm{On}$ the financial implications of the Migration Pact, see I. Goldner Lang, 'Financial Implications of the New Pact on Migration and Asylum: Will the Next MFF Cover the Costs?', 27 January 2020, 〈https://eumigrationlawblog.eu/financial-implications-of-the-new-pact-onmigration-and-asylum-will-the-next-mff-cover-the-costs/ $\rangle$, visited 13 July 2021.

${ }^{97}$ On the analysis of solidarity in the Migration Pact, see F. Maiani, 'A "Fresh Start" or One More Clunker? Dublin and Solidarity in the New Pact', Odysseus Blog, 20 October 2020, 〈https:// eumigrationlawblog.eu/a-fresh-start-or-one-more-clunker-dublin-and-solidarity-in-the-new-pact/ $\rangle$, visited 13 July 2021. For a discussion of solidarity in the context of the refugee crisis, see I. Goldner Lang, 'The EU Financial and Migration Crises: Two Crises - Many Facets of Solidarity', in A. Biondi et al. (eds.), Solidarity in EU Law: Legal Principle in the Making (Edward Elgar 2018) p. 133.
} 
borders (hereinafter: Screening Proposal). ${ }^{98}$ The aim of screening procedures is to strengthen the control of persons entering the Schengen area and to refer them to the appropriate procedure. ${ }^{99}$ During the screening procedure, third-country nationals will not be allowed to enter the territory of the member state unless it becomes apparent, during the screening, that they meet the entry conditions as required by the Schengen Borders Code. ${ }^{100}$ According to the Screening Proposal, screening will apply to all third-country nationals who have crossed the external border in an unauthorised manner, to those who have applied for international protection during border checks without fulfilling the entry conditions, as well as to those disembarked after a search and rescue operation. ${ }^{101}$ It will be performed by national authorities, which may be assisted by the European Border and Coast Guard Agency and the European Union Agency for Asylum. ${ }^{102}$ Additionally, each member state will have to establish an independent monitoring mechanism to ensure compliance with fundamental rights. ${ }^{103}$

Screening will comprise a health and vulnerability check; an identity check; registration of biometric data in the appropriate databases; a security check; the filling out of a de-briefing form; and a referral to the appropriate procedure. ${ }^{104}$ Most of these tasks (identity, registration and security checks and preliminary vulnerability assessments) are already part of member states' obligations based on the Schengen Borders Code and the Eurodac Regulation, whereas health checks will be a new obligation, based on EU asylum law, but member states have, in practice, already started conducting them in response to the Covid-19 pandemic. Nevertheless, these tasks will be highly demanding, both operationally and in terms of the protection of fundamental rights, due to short deadlines and the fact that they have to take place close to the borders. Screening activities will have to be completed within five days, with an additional five-day extension in the case of a migration influx. ${ }^{105}$ Obviously, the logic behind the Screening Proposal is to ensure speedy and streamlined channelling of the three categories

\footnotetext{
${ }^{98}$ Proposal for a Regulation of the European Parliament and of the Council introducing a screening of third country nationals at the external borders and amending Regulations (EC) No 767/2008, (EU) 2017/2226, (EU) 2018/1240 and (EU) 2019/817, COM(2020) 612 final, 23 September 2020. For an analysis of what is new and old in the Screening Proposal, see L. Jakulevičiené, 'Re-decoration of Existing Practices? Proposed Screening Procedures at the EU External Borders', Odysseus Blog, 27 October 2020, 〈https://eumigrationlawblog.eu/re-decoration-of-existingpractices-proposed-screening-procedures-at-the-eu-external-borders/ $\rangle$, visited 13 July 2021.

${ }^{99}$ Art. 1 of the Screening Proposal.

${ }^{100}$ Art. 4 of the Screening Proposal.

${ }^{101}$ Art. 1 of the Screening Proposal.

${ }^{102}$ Art. 6(7) of the Screening Proposal.

${ }^{103}$ Art. 7(2) of the Screening Proposal.

${ }^{104}$ Art. 6(6) of the Screening Proposal.

${ }^{105}$ Art. 6(3) of the Screening Proposal.
} 
of third-country nationals mentioned above to the asylum, border or return procedure, while protecting security and health. The challenge of such procedures will be to ensure speed and efficiency, while preserving asylum seekers' rights and preventing delays and the accumulation of people at the borders.

On the other hand, the establishment of an independent national monitoring mechanism will help protect fundamental rights only if the mechanism is truly independent, both in law and in practice, and provided it has adequate financial and human resources and financial and operational autonomy. ${ }^{106}$ Additionally, national monitoring mechanisms will be able to fulfil their role only if they have the power to conduct unannounced visits, have access to all documents, places and individuals, and if they can publish reports, make recommendations and make referrals directly to the national prosecution authorities. ${ }^{107}$ It is questionable whether member states will be willing to fulfil these requirements.

Once the screening procedure is over, third-country nationals will be channelled into asylum, border or return procedures. ${ }^{108}$ Border procedures in the suggested form are a novelty, stipulated by the amended proposal for a Regulation establishing a common procedure for international protection in the Union and repealing Directive 2013/32/EU (hereinafter: Amended Asylum Procedures Proposal). ${ }^{109}$

${ }^{106}$ United Nations High Commissioner for Refugees, 'Note on Joint Consultation on Independent National Monitoring Mechanisms proposed in the EU Pact on Migration and Asylum', 23 February 2021, 〈https://europe.ohchr.org/EN/NewsEvents/Pages/DisplayNews.aspx? NewsID $=2596 \&$ LangID $=E\rangle$, visited 13 July 2021. For critiques of the scope of proposed monitoring mechanism, see R. Lanneau, 'The Commission's proposal for a new Independent Monitoring Mechanism at the external border of the EU: a necessary but limited mechanism', Odysseus Blog, 22 February 2021, 〈https://eumigrationlawblog.eu/the-commissions-proposal-for-a-new-independentmonitoring-mechanism-at-the-external-border-of-the-eu-a-necessary-but-limited-mechanism/ $>$, visited 13 July 2021; Amnesty International, 'EU: Independent Monitoring Mechanism on EU Borders Must Ensure Fundamental Rights and Accountability', 6 November 2020, 〈https:// www.amnesty.org/en/latest/news/2020/11/eu-independent-monitoring-mechanism-on-eu-bordersmust-ensure-fundamental-rights-and-accountability/ $\rangle$, visited 13 July 2021.

${ }^{107}$ Note on Joint Consultation on Independent National Monitoring Mechanisms proposed in the EU Pact on Migration and Asylum', supra n. 106.

${ }^{108}$ According to Art. 14(2) of the Screening Proposal, if the third-country national has made an asylum claim, they will be referred to the asylum procedure, with an indication on the de-briefing form whether the applicant should be referred to the accelerated procedure or the border procedure.

${ }^{109}$ Amended proposal for a Regulation of the European Parliament and of the Council establishing a common procedure for international protection in the Union and repealing Directive 2013/ 32/EU, COM/2020/611 final, 23 September 2020. On the other hand, as stated in Art. 14(1) of the Screening Proposal, if the third-country national has not applied for asylum and does not meet the Schengen conditions for entry, they are referred to the return procedure. For an analysis of border procedures, see J. Vedsted-Hansen, 'Border Procedure: Efficient Examination or Restricted Access to Protection?’ Odysseus Blog, 18 December 2020, 〈https://eumigrationlawblog.eu/borderprocedure-efficient-examination-or-restricted-access-to-protection/ $\rangle$, visited 13 July 2021. 
The aim of a border procedure is 'to quickly assess at the external borders whether applications are unfounded or inadmissible and to swiftly return those with no right to stay', thus enabling member states 'to require applicants for international protection to stay at the external border or in a transit zone in order to assess the admissibility of applications. ${ }^{110}$ Consequently, the border procedure is conceptualised as a pre-entry step, that comprises a 'seamless', 'end-to-end' connection between assessing the asylum case and implementing a return decision if the application is rejected.

Even though border procedures do not preclude the host member state from carrying out the procedure for determining which member state is responsible for examining the asylum application, the intention behind the Amended Asylum Procedures Proposal is obviously to encourage widespread use of border procedures in frontline member states. Generally, national authorities are entitled to choose whether to channel the asylum applicant to a border procedure or a regular asylum procedure. ${ }^{111}$ However, it is likely that, in most cases, they will prefer to keep asylum applicants at the external borders instead of allowing them to enter deeper into the national territory. Additionally, border procedures will be compulsory in three cases: where an asylum seeker has presented false documents; where they are considered a danger to national security or public order; or if the applicant is of a nationality (or, in the case of a stateless person, is a former habitual resident) of a third country with a refugee recognition rate below $20 \%$, unless the circumstances in that country have changed or the asylum seeker belongs to a category of persons for whom the low recognition rate is not representative. ${ }^{112}$

Border procedures are intended to be highly efficient and fast. The whole procedure should not exceed 12 weeks, starting from the date when the application is registered for the first time, with an additional 12-week time limit for the return procedure. ${ }^{113}$ The short time limit poses considerable risks both in terms of the protection of applicants' rights and the feasibility of the whole procedure, especially in the case of high numbers of arrivals.

\footnotetext{
${ }^{110}$ Recital 40a of the Preamble to the Amended Asylum Procedures Proposal.

${ }^{111}$ Art. 41(1) of the Amended Asylum Proposal.

${ }^{112}$ Art. 40(1)(c), (f) and (i) of the Amended Asylum Proposal. By way of exception, a member state is not required to apply border procedures for nationals of a third-party country that does not cooperate sufficiently in readmission (Art. 41(4)). Additionally, the application of border procedures is limited with regard to unaccompanied minors, who can be subject to border procedures only provided they come from a safe third country, are considered a threat to national security or public order or have presented false documents (Art. 41(5)). Finally, border procedures do not apply to vulnerable applicants if adequate support cannot be provided within the framework of the border procedure (Art. 19(3)).

${ }^{113}$ Art. 41(11) of the Amended Asylum Procedures Proposal.
} 
The Amended Asylum Procedures Proposal obliges national authorities to provide the most important procedural guarantees, such as individual examinations of asylum applications, ${ }^{114}$ personal interviews, ${ }^{115}$ legal assistance and representation ${ }^{116}$ and the right to an effective remedy. ${ }^{117}$ However, practical adherence to these standards will be particularly challenging given that these procedures should be completed within 12 weeks from when the application is registered for the first time or, exceptionally, in 20 weeks in a crisis situation. ${ }^{118}$ Return procedures have to be completed in an additional 12 or, exceptionally, 20 weeks. ${ }^{119}$ Such short periods could further jeopardise asylum seekers' rights and encourage member states to accelerate the border and return procedure by disregarding their duty to ensure that asylum seekers will be protected in the receiving state in the case of return. Additionally, the facts that border procedures will take place at the external borders and that they will preclude the applicants' entry into the member states' territories implies that member states will in most cases resort to detention during the 12-week period, which further challenges asylum seekers' fundamental rights. ${ }^{120}$

Finally, the Migration Pact creates a dangerous cocktail as regards safe country concepts. Member states will be obliged to apply the 'safe country of origin', 'first country of asylum' and 'safe third country' rules, whereas the lists of 'safe countries of origin' and 'safe third countries' will be determined at the EU level. ${ }^{121}$ 'First country of asylum' and 'safe third country' cases will have to be declared inadmissible within ten working days, ${ }^{122}$ whereas 'safe country of origin' cases will be considered as manifestly unfounded and subject to accelerated procedures. ${ }^{123}$

${ }^{114}$ Art. 33(2) of the Proposal for a Regulation establishing a common procedure for international protection in the Union and repealing Directive, COM (2016) 467 final, 2013/32/EU, as confirmed by the 2020 amended proposal for the Asylum Procedures Regulation.

${ }^{115}$ Amended proposal for the Asylum Procedures Regulation, Arts. 10-13.

${ }^{116}$ Amended proposal for the Asylum Procedures Regulation, Arts. 14-17.

${ }^{117}$ Amended proposal for the Asylum Procedures Regulation, Art. 53.

${ }^{118}$ Amended proposal for the Asylum Procedures Regulation, Art. 41(11); Art. 4b of the Proposal for a Regulation addressing situations of crisis and force majeure in the field of migration and asylum, $\operatorname{COM(2020)} 613$ final, 23 September 2020,

${ }^{119}$ Amended proposal for the Asylum Procedures Regulation, Art. 41a(2); Proposal for the Crisis and Force Majeure Regulation, Art. 5(1)(a).

${ }^{120}$ Art. $41 \mathrm{a}(7)$ and Recitals 40f, $40 \mathrm{~h}$ and $40 \mathrm{i}$ of the Preamble to the Amended Asylum Procedures Proposal. According to Recital $40 \mathrm{f}$ of the Preamble, detention is not compulsory, but member states 'should nevertheless be able to apply the grounds for detention during the border procedure in accordance with the provisions of the [Reception Conditions] Directive'.

${ }^{121}$ Arts. 48 and 46 of the 2016 Proposal for the Asylum Procedures Regulation. National lists may be retained for five years.

${ }^{122}$ Art. 34 of the Proposal for a Regulation establishing a common procedure for international protection in the Union and repealing Directive 2013/32/EU, COM(2016) 467 final, 13 July 2016.

${ }^{123} 2016$ Proposal for the Asylum Procedures Regulation, Arts. 37(3) and 40(1)(e). 
The presence of all these categories will be decided in border procedures. The only silver lining is that the concept of 'sufficient protection' is defined in a humane way in the 2016 proposal, ${ }^{124}$ which is amended by the Pact. The 2016 proposal specifies that the 'first country of asylum' must ensure legal residence, access to labour market, healthcare, education and family reunification rights, which is confirmed by the Migration Pact.

\section{Conclusion}

The constitutional normative framework of this article relies on the theory by Kim Lane Scheppele, Dimitry Vladimirovich Kochenov and Barbara GrabowskaMoroz. In their comprehensive study on the enforcement of the values of Article 2 TEU they state: 'Given developments over the last decade, we can no longer presume that the EU is a Union of Rule-of-Law-based democracies, as its Treaties presume. The EU's moral appeal as well as the backbone of its legal system collapse when its member states no longer honour EU values. ${ }^{125}$ The aim of this article was to show that EU member states' asylum practices are weakening both the EU's normative framework and the values it is based upon. The article addresses the gap between the rule of law in the area of asylum and member states' practices, by revealing the continuum which ranges from member states' exploitation of ambivalences in terminology to outright breaches of the non-refoulement principle, as an EU core value enshrined in the Charter of Fundamental Rights and the Treaty. We have shown that whereas the EU's letter of the law does not call into question the protection of third-country nationals' fundamental rights, including the principle of non-refoulement, in reality these standards are challenged by member states' national practices, which range from rigid pushbacks and border police deterrence to subtler techniques which exploit legal uncertainties related to the concepts of 'safe third country', 'first country of asylum' and 'safe country of origin'. The EU institutions' acceptance of such practices further undermines the practical viability of the principle of non-refoulement. Unfortunately, the Migration Pact offers no cure for these flaws. In fact, in some respects, it will exacerbate the situation with extended periods of detention and fewer guarantees of the protection of fundamental rights. The situation is bleak, but this is no reason to remain silent about it.

\footnotetext{
${ }^{124} 2016$ Proposal for the Asylum Procedures Regulation, Art. 44(2).

${ }^{125}$ K.L. Scheppele et al., 'EU Values Are Law, After All: Enforcing EU Values through Systemic Infringement Actions by the European Commission and the Member States of the European Union', 39(1) Yearbook of European Law (2020) p. 3 at p. 5.
} 